baby facility in the acute psychiatric admission ward for over 10 years. We have facilities to admit up to three mothers and their babies at any one time and admit babies (up to 1 year of age). There is a nursery downstairs and a sleeping nursery upstairs where the babies sleep at night. The mothers have adjacent rooms. Over a two-year period from January 1984 to December 1985 we admitted 13 mothers with babies. Therefore, as can be seen, the facility is not always in use and the beds are used by general psychiatric patients at other times.

It is not difficult to provide this facility which does not entail special building requirements or additional staff. It was only rarely that we had three babies at the same time and needed additional nursing staff. Usually we have managed with the regular staff on duty. We have also not experienced any major problems having mothers with babies in an adult psychiatric unit from the other patients. It would have been extremely traumatic if these mothers had had to be admitted to a unit outside the catchment area miles away from their homes, both as regards visiting and later follow-up.

This facility has been well used by our catchment area population. All those admitted could not have been managed at home in spite of the fact that we have a very good community psychiatric nursing service with close liaison with the general practitioners. I would like to conclude therefore that, though the mother and baby facility is not in use all the time it serves a very important client group and should be available in all health districts in the country.

V. R. PANDIta-Gunawardena

Netherne Hospital

Coulsdon, Surrey

\section{Medicine for trainees?}

DeAr SIRS

The exam regulations permit one of the three premembership years to be spent in a recognised medical job, but is this a good idea? I believe so.

After house jobs I spent a year as a SHO in psychiatry, and after this brief introduction I returned to medicine, to a post involving six months in the 'specialties' (e.g. chest medicine, infectious diseases) and six months general medicine- thus providing broad experience.

It was worth while doing this medical job for several reasons: most obviously I simply learned more medicineacute, emergencies, how to differentiate the significant from the insignificant, resuscitation. I gained experience in outpatient management-the 'fine adjustment' of treatment, and the art of continuous review.

Did all this relate to psychiatric practice? Yes: as a psychiatrist I feel I acquire a responsibility for the patient's physical as well as mental wellbeing, most significant in the care of long-stay and psychogeriatric patients; I also found it not unusual in a psychiatric clinic that a patient had 'saved up' a medical problem.

Psychiatric disorder may be the presenting feature of medical problems or may complicate primary medical problems. Psychopathology influences time and mode of presentation of medical disorder and vice versa. In such cases a reasonable medical knowledge is necessary-cither to treat the medical aspect or simply to allow a better comprehension of all areas of the problem.

In medical practice I came across a wide variety of psychiatric symptomatology, ranging from the mild to the florid, and was frequently forced to ask myself whether formal therapy was justified-I certainly found myself considering 'caseness' much more critically as my year in medicine progressed. A year in medicine also provided an excellent opportunity for research into its psychiatric aspects as well as being a good source of ideas for later. Finally it added that 'something different' to improve my CV.

How about the problems posed by spending the extra time in medicine? There has been some concern expressed about the problems faced by applicants intending to pursue other career specialties in obtaining junior medical posts. I found no problem getting a medical SHO job for several reasons: I was not a stranger to the hospital, having been a houseman there. It is a district general in a (very arguably) "less desirable' area of the country, but the training given was more than adequate (and College recognised). Similar DGH posts are certainly accessible to others.

The clinical methodology, required knowledge apart, was very different in medical and psychiatric jobs and as a result I spent some weeks acclimatising after moving between specialties-furthermore keeping up with psychiatry became more difficult during the 'year out'.

Those are my arguments for and against a year in a medical SHO post. To spend a year in an alternative specialty prior to complete and final involvement in one's career specialty can, I feel, only produce a more mature, capable, and better rounded clinician. If medicine does not appeal, then how about paediatrics, or neurosurgery?

No doubt there are other arguments for and against 'extra-psychiatric' experience and hopefully these will be debated but, whatever one's personal opinion, it is an option that at least should be considered.

K. A. Wood

The Bethlem Royal Hospital

Beckenham, Kent

\section{NHS Central Register}

Dear Sirs

Drs O'Connor and Daly, in their article 'The Problems of Tracing' (Bulletin, March 1986, 10, 51-52) do not mention one important aid that is available to researchers in England and Wales. The National Health Service Central Register at Southport is able to provide the address of the Family Practitioner Committee with which a patient is registered. To obtain this information the most valuable lead is the NHS number. However, if this is not available, as it is extremely unlikely to have been recorded in the patient's notes in a hospital admission, the full name and exact date of birth would in most cases enable that patient to be 
traced. Once the FPC is known it is possible to write to them and obtain the name and address of the GP the patient is registered with and to make contact through the patient's GP.

A guide to the use of the National Health Service Central Register (NHSCR) as an aid to medical research is available from the Chief Medical Statistician (Department MR), OPCS, Medical Statistics Division, St. Catherine's House, 10 Kingsway, London WC2B 6JP.

The Central Register proved to be an extremely useful aid in tracing patients in a study ${ }^{1}$ completed recently.

Harsha RATNASURIYa

The Maudsley Hospital

London SES $8 A Z$

REFERENCE

'RAtnasuriya, R. H., Eisler, L., Szmukler, G. I. \& Russell, G. F. M. (1986) Anorexia nervosa: Outcome and prognostic factors after 20 years. (In preparation).

\section{Psychiatry and surrealism}

Dear Sirs

I was interested to read Patrick Bracken's recent account of psychiatry and surrealism (Bulletin, April 1986, $10,80-81)$.

The surrealists freely acknowledged the influence of some psychoanalytical concepts on their work. In fact they considered Eros to be the source of their artistic drive. Breton declared " "Of Eros and the struggle against Eros", in its enigmatic form, this exclamation of Freud's obsesses me some days as only certain passages of poetry can'1. The art historian Robert Short remarked that 'Eros presided over the surrealist experience of beauty in all its forms' 2 .

They were less ready, however, to accept the influence of the death instinct, despite widespread suggestions of its presence in their work. Depersonalised faces haunt Magritte's paintings; morbid desolation pervades Delvaux's 'Call of the Night'; even Bellmer's 'Doll', in spite of its erotic intention, has a cadaverous quality. There are many more examples.

In surrealist art, eroticism and aggression, destruction and creation, life and death are inseparably intertwined. Yet its creators predominantly highlighted the role of Eros and neglected that of the death instinct. But death was not unfamiliar to them; Jacques Vache committed suicide as did Magritte's mother. Perhaps they found unpalatable 'this daemonic concept' described by Freud which 'could bring so little comfort to him or anyone else's.

Greaves Hall Hospital

Patricia Abbott

Southport, Merseyside

References

'Breton, A. (1937) L'Amour Fou. Paris: Gallimard p. 50.

2ShORT, R. (1980) Dada and Surrealism. London: Octopus. p. 147.

${ }^{3}$ Stafrord-Clark, D. (1965) What Freud Really Said. London: Penguin. p. 160.
DeAr Sirs

Patrick Bracken's article on psychiatrists and surrealism opens up some interesting questions but surrealism was never as anti-psychiatric as it claimed. One leading Dadaist, Huelsenbeck, became a psychoanalyst, and Lacan was a surrealist himself, not merely a sympathiser.

The surrealists' response to their erstwhile member Antonin Artaud is significant. Artaud had maintained that 'delirium is as legitimate, as logical, as any other succession of human ideas'1. When he was later hospitalised with schizophrenia he appealed to his former colleagues to rescue him from his doctors: 'The initiates have real instruments of torture ... and they use them from afar to mutilate me a little more every night while I am asleep'2. The surrealists (who had maintained, like the anarchists, that mental patients were political prisoners along with criminals and conscripted soldiers) failed to respond. In practice surrealism accepted the social sequestration of madness. As to the meretricious Dali, Clive Bell correctly pointed out that Freud's aesthetic sensibilities approximated to those of a housemaid; Dali was soon expelled by Breton for his reactionary tendencies.

ROLAND LITTLEWOOD

University of Birmingham

All Saints Hospital

Birmingham

REFERENCES

'Artaud, A. (1970) Lettres aux Medicins- Chefs des Asiles de Fous. Oeuvres Complètes. Paris: Gallimard.

${ }^{2}$ Essurn, M. (1976) Artaud. London: Fontana

\section{Forthcoming Events}

The British Postgraduate Medical Federation are at present holding a series of educational courses and workshops ending in March 1987. Information: Mrs Elva Macklin, Education Department, British Postgraduate Medical Federation, 33 Millman Street, London WCIN 3EJ.

The Midland Course in Group Wort and Family Therapy in association with the Institute of Group Analysis (London) will be holding courses in Oxford (September 1986-May 1987) and in Northampton (October 1986-June 1987) on a weekly half-day basis. They will be of interest to doctors, social workers, psychologists, nurses or others working with small or large groups, including naturally occurring groups. Course fee is $£ 250$. Information: Mrs Ros Clarke, Course Secretary (Oxford), Chaplain's Office, Littlemore Hospital, Littlemore, Oxford OX4 4XN or to Mrs L. Bardakovic, Course Secretary, Mayfair Day Hospital, 32-34 Headlands, Kettering, Northampton. There is also the possibility, if sufficient interest is shown, for supervision sessions to be arranged for those who have been students on previous Midland Courses. Those interested should write 